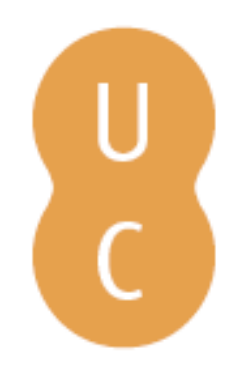

\title{
pกmpalina
}

\section{Dynamics of sediment-associated nutrients if mountainous rivers: a case study in northern Portugal}

\author{
Autor(es): $\quad$ Reis, A.; Parker, A.; Alencoão, A. M. P.; Oliveira, A. Sousa \\ Publicado por: Imprensa da Universidade de Coimbra \\ URL \\ persistente: URI:http://hdl.handle.net/10316.2/31475 \\ DOI: $\quad$ DOI:http://dx.doi.org/10.14195/978-989-26-0534-0_40 \\ Accessed : $\quad$ 26-Apr-2023 09:09:37
}

A navegação consulta e descarregamento dos títulos inseridos nas Bibliotecas Digitais UC Digitalis, UC Pombalina e UC Impactum, pressupõem a aceitação plena e sem reservas dos Termos e Condições de Uso destas Bibliotecas Digitais, disponíveis em https://digitalis.uc.pt/pt-pt/termos.

Conforme exposto nos referidos Termos e Condições de Uso, o descarregamento de títulos de acesso restrito requer uma licença válida de autorização devendo o utilizador aceder ao(s) documento(s) a partir de um endereço de IP da instituição detentora da supramencionada licença.

Ao utilizador é apenas permitido o descarregamento para uso pessoal, pelo que o emprego do(s) título(s) descarregado(s) para outro fim, designadamente comercial, carece de autorização do respetivo autor ou editor da obra.

Na medida em que todas as obras da UC Digitalis se encontram protegidas pelo Código do Direito de Autor e Direitos Conexos e demais legislação aplicável, toda a cópia, parcial ou total, deste documento, nos casos em que é legalmente admitida, deverá conter ou fazer-se acompanhar por este aviso.

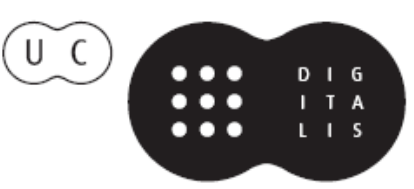



40

\title{
DYNAMICS OF SEDIMENT-ASSOCIATED NUTRIENTS IN MOUNTAINOUS RIVERS: A CASE STUDY IN NORTHERN PORTUGAL
}

\author{
DINÂMICA DE NUTRIENTES ASSOCIADOS \\ A SEDIMENTOS EM RIOS DE MONTANHA: \\ UM CASO DE ESTUDO NO NORTE DE PORTUGAL
}

\author{
A. Reis ${ }^{1}$, A. Parker ${ }^{2}$, A. M. P. Alencoão ${ }^{1} \&$ A. Sousa Oliveira ${ }^{1}$
}

\begin{abstract}
Samples of fine-grained river bed sediment were collected in the mountainous rural catchment of the River Corgo, which drains crystalline rocks, in order to investigate seasonal, spatial and downstream changes in the total $\mathrm{N}(\mathrm{TN})$ and total $\mathrm{P}$ (TP) contents associated to the size-fraction $<63 \mu \mathrm{m}$. The sediments are composed mainly by detrital minerals (76-95\%) and illite, kaolinite and various mixed-layer and poorly crystallized clay species are the main constituents of the clay fraction. The silt size-class is dominant (84-87\%). The TN and TP contents vary, respectively, in the range 0.3 to 14 $\mathrm{g} / \mathrm{kg}$ and 0.2 to $5.1 \mathrm{~g} / \mathrm{kg}$. The spatial and seasonal trends suggest that the major controls of the input and dispersion of sedimentary TN and TP in the fluvial environment are: seasonal and interannual variability in stream discharge; morphology of the river and the steepness of the riverbed; movement into the river channel of soil particles with associated nutrients; land use, point and non-point source contamination.
\end{abstract}

Keywords - Mountainous river; Bottom sediments; Nutrients; Nitrogen; Phosphorus

Resumo - Nesta contribuição são apresentados resultados sobre um estudo realizado em sedimentos finos do leito fluvial recolhidos na rede de drenagem do rio Corgo, que drena uma bacia rural de montanha, em substrato de rochas cristalinas. O objetivo é investigar o padráo de distribuição sazonal e espacial dos teores totais de $N(T N)$ e P $(T P)$ associados à fraçáo sedimentar

\footnotetext{
1 Department of Geology, University of Trás-os-Montes e Alto Douro, Vila Real, Portugal; Centre of Geophysics from the University of Coimbra, Coimbra, Portugal; anarreis@utad.pt; alencoao@utad.pt; soliveira@utad.pt

2 Soil Research Group, School of Human and Environmental Sciences, University of Reading, Reading, UK; aparker@reading.ac.uk
} 
$<63 \mu \mathrm{m}$. A composição dos sedimentos é essencialmente detritica (76-95\%), predominando na fração argilosa a ilite, e diversos minerais de argila interestratificados e espécies fracamente cristalinas. O silte é a classe granulométrica dominante (84-87\%). Os teores de TN e TP variam

no intervalo 0,3 a $14 \mathrm{~g} / \mathrm{kg}$ e 0,2 a 5,1 g/kg, respetivamente. As tendências espaciais e temporais observadas sugerem que o input e a dispersão de TN e TP, na forma particulada, no ambiente fluvial, são controlados principalmente por: variabilidade sazonal e interanual dos caudais; morfologia fluvial e irregularidade do leito; movimento de particulas de solo, com nutrientes associados, para os canais fluviais; ocupação do solo e fontes de contaminação pontuais e difusas.

\section{Palavras-chave - Rio de montanha; Sedimentos do leito; Nutrientes; Azoto; Fósforo}

\section{1 - Introduction}

Oxic river sediments have a significant influence on surface water quality, owing to their role both as a sink and a potential source of pollutants. Fine-grained sediments usually show increasing concentrations of contaminants and nutrients downstream, and there is thus an increasing awareness of the importance of non point-source pollution in fluvial systems. As stated by Symader et al. (2007), bottom sediments of small rivers in mountainous areas behave like a transport system of its own and show high temporal variation in their chemical composition. MEYBECK (1982) estimated that sediment-associated transport contributes approximately 55 and 95\%, respectively, of the total $\mathrm{N}$ and P flux. WALLING et al. (2001), in a detailed investigation of nutrient fluxes in four British rivers, estimated that sediment-associated transport accounted for $26-75 \%$ of the annual total-P load and 3-8\% of the annual total-N load, varying from river to river in response to local conditions. Differences among the individual rivers were shown to reflect the magnitude of the specific suspended sediment yield and the nutrient content of the suspended sediment transported by the river. These, in turns reflect the influence of catchment characteristics such as relief, geology, soil types and land use, the hydrometeorological conditions, the relative importance of point source inputs and the potential for nutrient uptake by the sediment from the water column.

In fluvial environments from mountainous catchments, the dynamics of sediment particles and particle-bound contaminants and nutrients are still poorly understood. The transport of significant sedimentary loads, as suspended matter, in short periods of time, mainly in winter, poses some issues concerning monitoring and modelling approaches of the transport and fate of micro-pollutants and nutrients at the catchment scale. This study reports results of a case study on the investigation about fluvial sediments' quality in a mountainous rural meso-scale catchment, located in the NE of Portugal. The aim was to evaluate the retention and/or mobilisation of nutrients, derived from agricultural and urban activities, in oxic fluvial sediments, as well as its variability in space and time overall the basin area.

\section{2 - Study area}

The River Corgo traverses Vila Real city, is a tributary of the River Douro and its catchment, up to the gauge station of Ermida, covers an area of approximately $295 \mathrm{~km}^{2}$. 
In the southern part of the basin, Palaeozoic metasediments outcrop (Fig. 1). These are composed essentially of alternating phyllites and greywackes, dating from the Cambrian (SOUSA, 1982), and a conglomerate overlain by alternating quartzites and phyllites, with iron-rich levels interlayered (PEREIRA, 1989), dating from the Ordovician. In the northern part of the basin, granites intruded the older metamorphic rocks. The oldest ones are two-mica, fine to medium-grained (PEREIRA, 1989; GOMES, 1989; MATOS, 1991; NEIVA \& GOMES, 1991, 2001); the most recent are biotitic granites (PEREIRA, 1989, MARTINS, 1998).

Locally the crystalline rocks are covered by sedimentary deposits from the Cenozoic, with major expression in the Campeã valley, in the southwest area, the Vila Pouca de Aguiar valley (LOURENÇO, 1997), in the northern area, and Vila Real basin (BAPTISTA, 1998). These valleys have a plan basement; downstream these, the channels became narrow and incised, alternating between steep riffles and quiet pools. The deposition of these sediments was controlled mainly by the major tectonic structure Penacova-Régua-Verin fault (GUTIÉRREZ CLAVEROL et al., 1987), which originated the Vila Real basin and the Telóes basin in Vila Pouca de Aguiar, along this fault zone.

The altitudes in the basin vary between $300-1400 \mathrm{~m}$. The land is occupied mainly by forest and natural vegetation in the highlands, and agriculture, which predominates in the valleys. Urban settlements are spread throughout the basin area. Industrial activity is scarce.

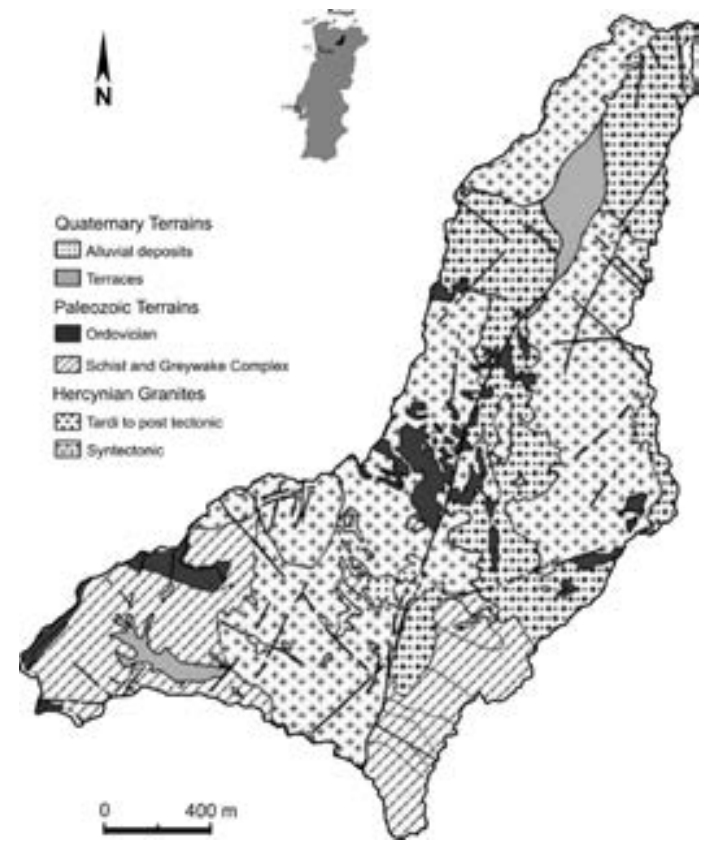

Fig. 1 - Simplified geological map of Corgo River Basin (modified from Portuguese Geological Map at 1:200000 scale, Sheet 2) (PEREIRA, 2000).

\section{3 - Methodology}

The data used in this research programme result from sampling campaigns done in the years 2004 and 2005, at the end of the Wet Period (WP) in April, and at the end of the Dry 
Period (DP) in September-October. The sampling was planned to obtain a representative spectrum of the variability of the studied parameters in conditions of high and low flow. The year of 2004 was characterized by a rainy winter, followed by a very dry summer period. The year of 2005 was characterized by a comparatively less-rainy winter but with some rain events during the dry period, so the summer period was comparatively less dry.

At each sampling site, a composite sample of bottom sediments was taken manually; the finer and most recently deposited sediment was preferentially sampled - approximately the uppermost $2-3 \mathrm{~cm}$ below the interface water-sediment. The samples were kept at $4{ }^{\circ} \mathrm{C}$, prior to analysis. Sediments were wet-sieved to separate the $<63 \mu \mathrm{m}$ fraction (FÖRSTNER, 2004). A total of 220 stream sediment samples were collected and analysed.

The identification of whole-rock and clay mineralogy was performed by $\mathrm{x}$-ray diffraction, with estimation of the mineral proportions, and SEM analysis of sediment grains was undertaken on selected samples (details in REIS, 2010). Particle-size distribution in the $<63 \mu \mathrm{m}$ grain-size fraction was determined by laser diffraction (details in REIS, 2010).

Total $\mathrm{N}$ and $\mathrm{P}$ were determined by sulphuric acid - Se digestion, and contents determined by spectrometry (HOUBA et al., 1995). In each analytical sequence, replicates were used to assess repeatability and an in-house reference material was used to ensure accuracy. The precision of the measurements is about $\pm 5 \%$.

\section{$4-$ Results and discussion}

\section{1 - Mineralogy and physical properties of the stream sediments}

The bulk mineralogical analysis of the $<63 \mu \mathrm{m}$ size-fraction indicates quartz, micas biotite and muscovite, and feldspars - both potassium and plagioclase, to be the main constituents. The abundance of detrital minerals in the sediment (76-95\%), and the occurrence of illite and various mixed-layer and poorly crystallized clay species in the clay fraction, reflects its origin in the saprolites and topsoils of the basin. It seems that little mineralogical evolution towards more developed weathering products occurs during transport along the drainage network. The expandable clays, although occurring in low contents, show slightly higher values in the samples from the large valleys (Campeã, Vila Pouca de Aguiar). Two different sequences of weathering were identified: one is influenced by the occurrence of chlorite minerals, leading to the dominance of vermiculite in the expandable minerals fraction (characteristic of Campeã valley); the other is derived from the acid rocks, leading to an important smectitic component in the expandable minerals.

The morphology and inter-particle relationships observed by SEM indicate high quantity of composite particles (Fig. 2). The clay-sized material is reduced occurring in flocs. Iron oxides seem to be widely dispersed in particles as coatings on the surfaces of minerals, and as spherical discrete particles. Spherical alumino-silicates are disseminated in sediments.

The particle-size distributions, typified by long fine tails, indicate that in general the sediments show minor spatial and temporal variations of granulometric characteristics. The silt size-class is dominant (84-87\%). The sediments are classified as coarse to medium silt, with medians of 11.4 to $22.3 \mu \mathrm{m}$, poorly sorted, with positive skewness. No consistent pattern is observed along the main lengths of the streams, mostly owing to the tributary contributions, which provide a surplus of entering material that superimposes the river processes of abrasion of particles and hydraulic sorting. 
a)

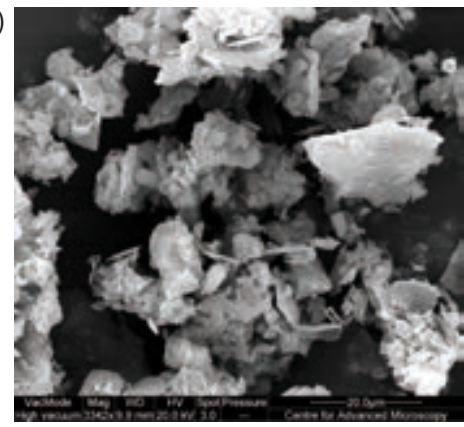

b)

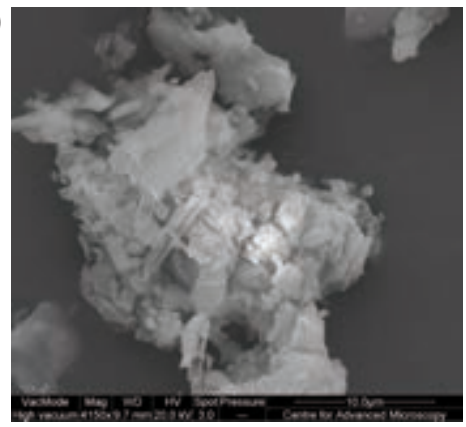

Fig. 2 - SEM microphotographs of representative distribution of sediment particles: a): mineral suites composed essentially by quartz, feldspars, mica, clay and composite particles;

b) flocs composed mainly by clay, silt-clay particles and some organic material.

\section{$4.2-\mathrm{N}$ and $\mathrm{P}$ in the stream sediments}

The variation range of total $\mathrm{N}(\mathrm{TN})$ and $\mathrm{P}(\mathrm{TP})$ contents differentiated for the sub-basins of the River Corgo catchment are shown in Fig. 3. The TN and TP contents of the sediments vary, respectively, in the range 0.3 to $14 \mathrm{~g} / \mathrm{kg}$ and 0.2 to $5.1 \mathrm{~g} / \mathrm{kg}$, with slight seasonal variations in samples from the same sampling sites. In the River Sordo sub-basin (SW) and in the southern-east tributary, on the left margin, the organic contents are consistently lower, in the range $0.3-7.1 \mathrm{~g} / \mathrm{kg}(\mathrm{TN})$ and $0.4-2.7 \mathrm{~g} / \mathrm{kg}$ (TP); in the Vila Pouca de Aguiar valley, in the River Cabril sub-basin and in sampling stations southward Vila Real these contents are generally higher, varying in the ranges $0.7-14.0 \mathrm{~g} / \mathrm{kg}$ for $\mathrm{TN}$ and $0.53-5.06 \mathrm{~g} / \mathrm{kg}$ for TP.
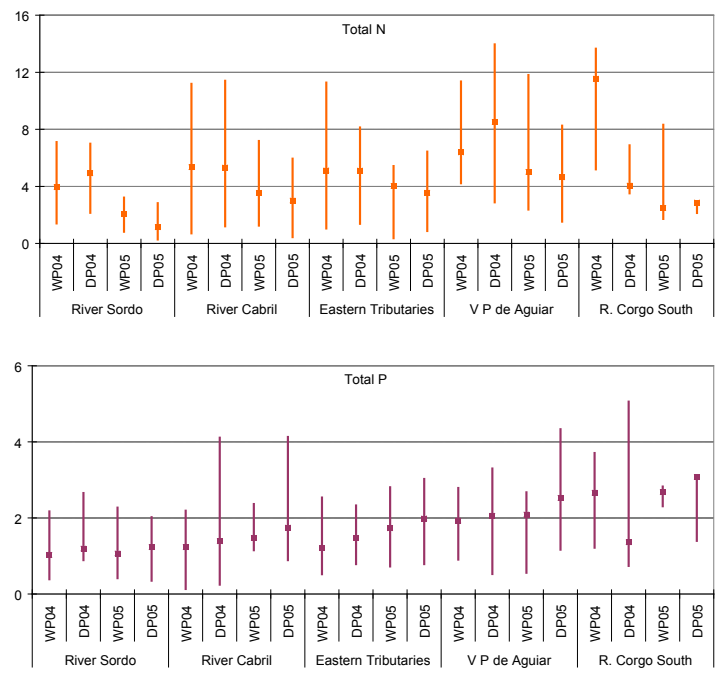

Fig. 3 - Variation range and median value of the total $\mathrm{N}$ and $\mathrm{P}$ contents $(\mathrm{g} / \mathrm{kg})$ River Corgo $<63 \mu \mathrm{m}$ sediment fraction, for the years 2004 and 2005, at the end of the Wet Period (WP) and the Dry Period (DP). 
Considering the values of TN and TP found in the River Corgo sediment's in the context of the values reported in the literature for other fluvial systems, these are within the ranges described, a few values are relatively higher, in particular TN. WALLING et al. (2001) and OWENS \& WALLING (2002) report TN and TP concentration ranges of $2.3-5.5 \mathrm{~g} / \mathrm{kg}$ and $1.1-5.9 \mathrm{~g} / \mathrm{kg}$, respectively, in sediments of UK rivers. HUANG et al. (2007) refer concentrations in sediments of a riverine system in China of $1.9-4.8 \mathrm{~g} / \mathrm{kg}$, for TN, and 0.7-3.4 g/kg for TP. VAROL \& SEN (2012) found that the TN and TP contents range in sediments of River Tigris were $0.7-2.7 \mathrm{~g} / \mathrm{kg}$ and $1.0-2.1 \mathrm{~g} / \mathrm{kg}$, respectively. DAVIDE et al. (2003) reported TN contents in bed sediments of the river Po within a range of $0.6-7.2 \mathrm{~g} / \mathrm{kg}$.

The mapped spatial distribution of TN and TP contents in the sediments of the River Corgo, from the four campaigns from 2004 and 2005, are shown in Fig 4 and Fig.5. The values of TN are, in general, relatively higher in 2004. In the agricultural valleys of Campeã and Vila Pouca de Aguiar higher contents of TN are found in samples from the Wet Period campaign. The TP contents are relatively higher in the Dry Period of 2005. Taking into consideration the rainfall - river flow regime during both years of sampling, the spatial and seasonal trends suggest that the major controls which affect the input and dispersion of sedimentary TN and TP in the fluvial environment are:

a) seasonal and interannual variability in stream discharge: in years of low precipitation an increase in nutrient contents associated with sediments should be expected, in particular TN; on the one hand intense precipitation events lead to an increase in quantity of soil particles transported into the drainage network, on the other hand, finer sediments remain deposited in riverbed longer leading to a relative increase of contents;

b) morphology of the river and the steepness of the riverbed: the sites exhibiting the higher and/or anomalous contents are in general located along downstream reaches of the main tributaries and in reaches with the riverbed less irregular, where there is a slightly higher accumulation of finer sediments; in the upland areas soils have low nutrient contents;

c) movement into the river channel of soil particles with associated nutrients, mainly derived from agriculture activities; $\mathrm{N}$ seems to be more affected by this effect, showing local higher contents at the end of the Wet Period;

d) land use, point and non-point source contamination: in sampling sites located in the vicinity of identified point pollution sources in the basin, there is an increase of nutrient contents; P seems to be more susceptible to the influence of point source contamination.

\section{5 - Concluding remarks}

The results obtained point towards a characteristic behaviour of more hydrodynamic fluvial systems. The sediments transported in the drainage system are essentially detrital in origin, derived from soils and weathering products. It seems that little mineralogical evolution towards more developed weathering products occurs during transport along the drainage network. The soil particles seem to be a significant pathway of transport and entrance of nutrients in the fluvial network by runoff, especially in the Wet Period, when the sediments are frequently remobilised. The morphology of the streambed exerts 

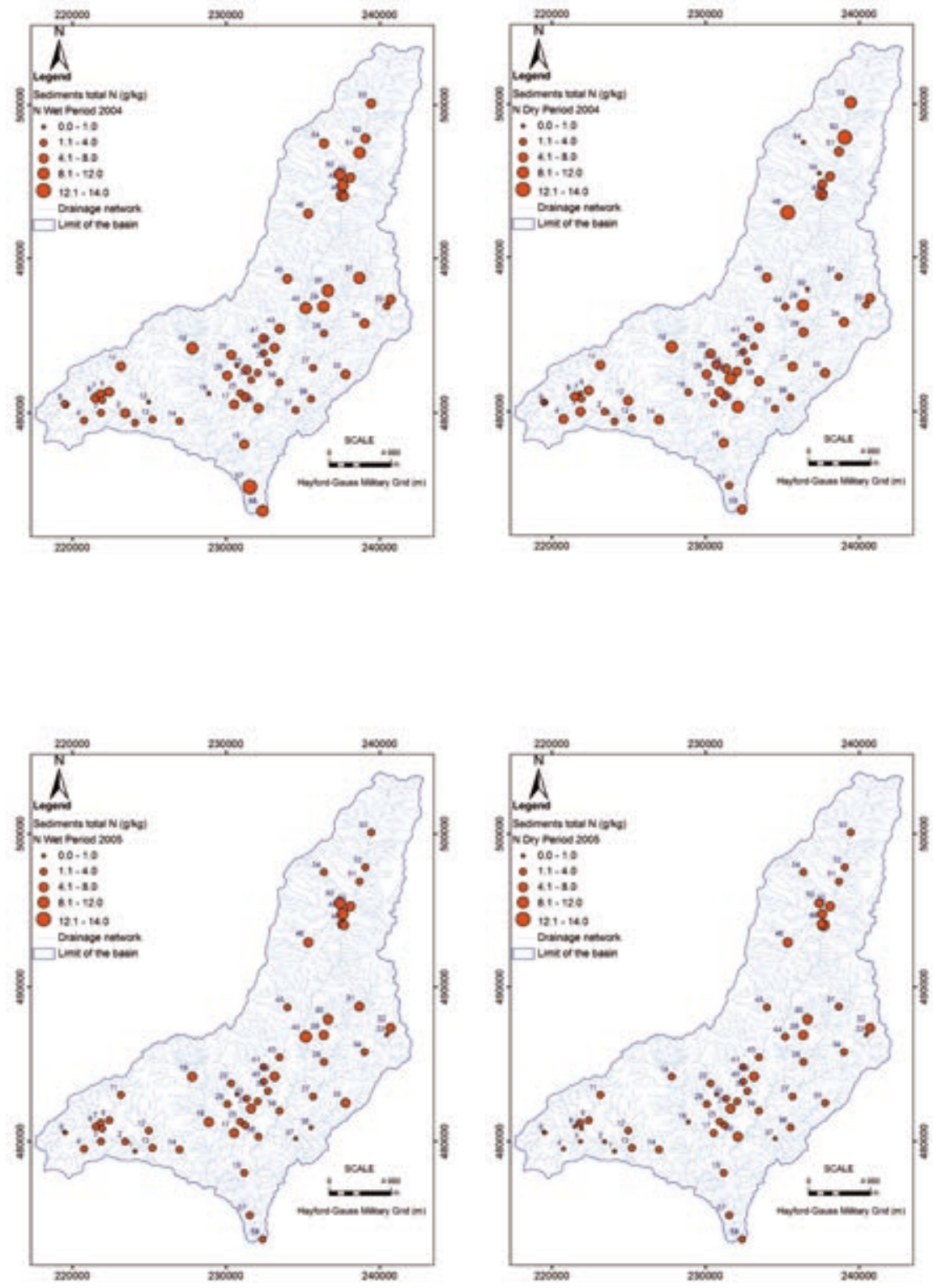

Fig. 4 - Distribution of the total N values ( $\mathrm{g} / \mathrm{kg}$ ) of the River Corgo sediment's $<63 \mu \mathrm{m}$ fraction, for the years 2004 and 2005, at the end of the Wet Period (WP) and the Dry Period (DP). 

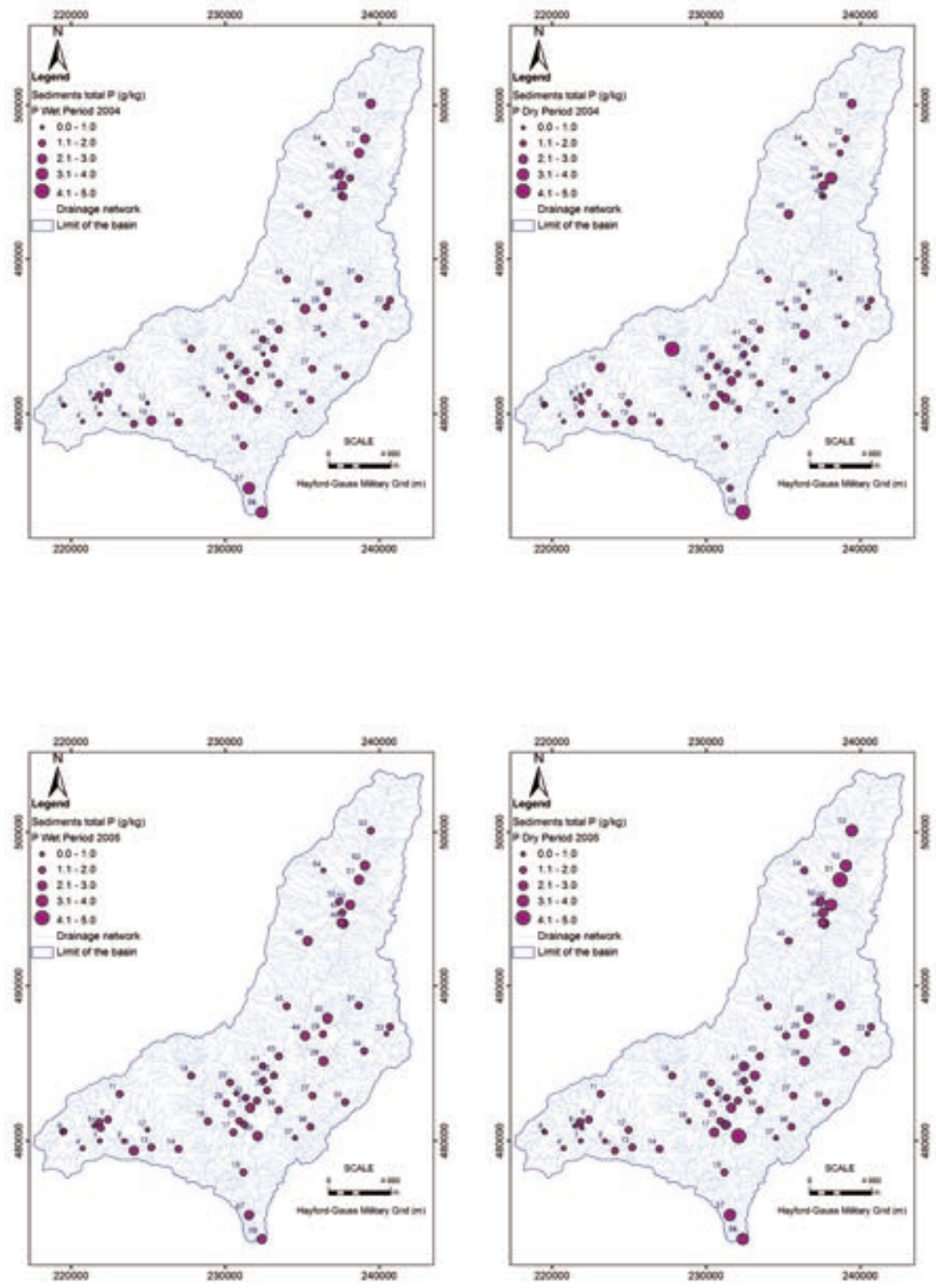

Fig. 5 - Distribution of the total P values $(\mathrm{g} / \mathrm{kg}$ ) of the River Corgo sediment's $<63 \mu \mathrm{m}$ fraction, for the years 2004 and 2005, at the end of the Wet Period (WP) and the Dry Period (DP). 
a major influence on the distribution of the sediment-associated nutrients in the fluvial environment. The influence of the point pollution sources in the basin, are reflected by a local increase of nutrient contents, indicating that even in more energetic streams the sediments control, to a significant extent, the levels of nutrients in the fluvial water.

Acknowledgments - The first author is grateful to the Calouste Gulbenkian Foundation and Portuguese Foundation for Science and Technology for the scholarship grants in the University of Reading, UK. The authors are also grateful to Miss Anne Dudley, Mr. Martin Heaps, Mr. David Thornley and Mr. Mike Andrews for the analytical work assistance in the Soil Science Department of the University of Reading.

\section{References}

BAPTISTA, J. (1998) - Estudo neotectónico da Zona de Falha Penacova-Régua-Verin. PhD Thesis (unpublished), University of Trás-os-Montes e Alto Douro, Vila Real, 346 p.

DAVIDE, V., PARDOS, M., DISERENS, J., UGAZIO, G., THOMAS, R., \& DOMINIK, J., (2003) Characterisation of bed sediments and suspension of the River Po (Italy) during normal and high flow conditions. Water Research 37, p. 2847-2864.

FÖRSTNER, U. (2004) - Traceability of sediment analysis. Trends in Analytical Chemistry, 23, 3.

GOMES, M E. P. (1989) - Geoquímica dos granitóides e seus minerais da região de Telóes-Vilarinho da Samardā. MSc. Thesis (unpublished), University of Aveiro, Aveiro.

GUTIÉRREZ CLAVEROL, M., LUQUE, C. \& SUÁREZ, V. (1987) - El lineamento tectonico Nazare (W de Portugal) - Luarca (NW de Espana) y su implicacion metalogenetica (Macizo Hesperico). In: Bea, A. C. F., Gonzalo, J. C. \& Rodrigues, J. M. L. (eds.). Geologia de los granitóides e rocas asociadas del Macizo Hespérico. Libro de Homenage a L. C. Garcia Figueirola Madrid: Editorial Rueda, p. 447-455.

HOUBA, V. J. G., VAN DER LEE, J. J. \& NOVOZAMSKY, I. (1995) - Soil Analysis Procedures (Soil and Plant Analysis, part 5B). Wageningen Agricultural University.

HUANG, B., ZHAO, Y., SHI, X., YU, D., ZHAO, Y., SUN, W., WANG, H. \& ÖBORN, I., (2007) - Source identification and spatial variability of nitrogen, phosphorus, and selected heavy metals in surface water and sediment in the riverine systems of a peri-urban interface. Journal of Environmental Science and Health, Part A 42, 371-380.

LOURENÇO, J. M. M. (1997) - Um estudo geológico da Bacia de Telôes. MSc Thesis (unpublished), University of Trás-os-Montes e Alto Douro, Vila Real, 122 p.

MARTINS, H. C. B. (1998) - Geoquímica e petrogénese de granitóides biotíticos tarditectónicos e pós-tectónicos: implicaçōes metalogénicas. MSc Thesis (unpublished), University of Trás-os-Montes e Alto Douro, Vila Real, 288 p.

MATOS, A. V. (1991) - A geologia da região de Vila Real. PhD Thesis (unpublished), University of Trás-os-Montes e Alto Douro, Vila Real, 312 p.

MEYBECK, M. (1982) - Carbon, nitrogen and phosphorus transport by world rivers - American J. Science, $282,401-450$.

NEIVA, A. M. R. \& GOMES, M. E. P. (1991) - Geochemistry of the granitoid rocks and their minerals from Lixa do Alvão - Alfarela de Jales - Tourencinho (Vila Pouca de Aguiar, northern Portugal). Chem. Geology, 89, p. 305-327. 
NEIVA, A. M. R., \& GOMES, M. E. P. (2001) - Diferentes tipos de granitos e seus processos petrogenéticos: Granitos Hercínicos Portugueses. Memórias da Academia de Ciências de Lisboa, XXXIX, p. 53-95

OWENS, P. N. \& WALLING, D. E. (2002) - The phosphorus content of fluvial sediment in rural and industrialized rivers basins. Water Research, 36, p. 685-701.

PEREIRA, E. (1989) - Notícia Explicativa da folha 10-A Celorico de Basto. Direcção Geral de Geologia e Minas. Serviços Geológicos de Portugal. Lisboa.

PEREIRA, E. G. C., (2000) - Carta Geológica de Portugal, Escala 1:200000 (Folha 2), Serviços Geológicos de Portugal.

REIS, A. R., 2010 - Occurrence and mobilisation of non-organic micro-pollutants in mountainous riverine systems. PhD Thesis (unpublished), University of Trás-os-Montes e Alto Douro, Vila Real, 453 pp.

SOUSA, M. B. (1982) - Litoestratigrafia e Estrutura do "Complexo Xisto-Grauváquico ante-Ordovícico"Grupo do Douro (Nordeste de Portugal). PhD Thesis (unpublished), University of Coimbra, Coimbra.

SYMADER, W., BIERL R., KURTENBACH, A. \& KREIN, A. (2007) - Transport Indicators. In: Westrich, B. \& Forstner, U. (eds.). Sediment Dynamics and Pollutant Mobility in Rivers. Springer, p. 269-304.

VAROL, M. \& SEN, B. (2012) - Assessment of nutrient and heavy metal contamination in surface water and sediments of the upper Tigris River, Turkey. Catena, 92, p. 1-10.

WALLING, D.E., RUSSELL, M.A. \& WEBB, B.W. (2001) - Controls on the nutrient content of suspended sediment transported by British rivers. Sci. Tot. Environ, 266, p. 113-123. 